\title{
Comparison of Vibrio cholerae 01 isolates by polymerase chain reaction fingerprinting and ribotyping
}

\author{
Y.-H. SHANGKUAN, C.-M. TSAO and H.-C. LIN \\ Division of Bacteriology, Institute of Preventive Medicine, National Defense Medical Center, PO Box 90048- \\ 700 Sanhsia Taipei, Taiwan 237, Republic of China
}

\begin{abstract}
The rRNA gene restriction patterns and the polymerase chain reaction (PCR) fingerprinting types of 53 Vibrio cholerae $O 1$ isolates were studied. Five and eight patterns were observed from 27 toxigenic and 26 non-toxigenic 01 isolates after $B g l I$ cleavage. PCR fingerprinting with three primer sets aimed at enterobacterial repetitive intergenic consensus (ERIC) sequences, ERIC-related sequences in $V$. cholerae, another kind of repeated sequences in $V$. cholerae (VCR) and arbitrary sequences divided the same strains into seven and 10 PCR types, respectively. Eight ribotypes had unique PCR patterns. PCR fingerprinting identified more than one pattern among isolates within each of the remaining ribotypes. However, ribotyping was able to differentiate the same PCR types in one case. A single ribotype and a single PCR pattern were found in toxigenic $O 1$ strains isolated in Taiwan from imported food and imported cases of cholera between 1993 and 1995 . Typing of $V$. cholerae O1 by PCR fingerprinting correlated well with ribotyping, but was more discriminating. PCR assay provides a rapid and simple means of typing these strains for epidemiological studies.
\end{abstract}

\section{Introduction}

Vibrio cholerae is the causative agent of cholera which, in its most severe form, is characterised by profuse diarrhoea, vomiting and muscle cramps. Until cholera epidemics caused by $V$. cholerae 0139 occurred in 1992 and 1993, all epidemic cases of cholera were associated with $V$. cholerae strains of $\mathrm{O}$ group 1 (O1 strains $[1,2]$. There are only two biotypes, classical and El Tor, and two serotypes, Inaba and Ogawa, of the $\mathrm{O} 1$ serotype [3]. The earliest isolates of $V$. cholerae $\mathrm{O} 1$ belongs to the classical biotype. The El Tor biotype strain was isolated from a cholera-like illness in the 1950s in Hong Kong, but did not become epidemic until 1960 in Indonesia, marking the beginning of the current and seventh pandemic [4, 5]. To cause symptoms of cholera, a strain of $V$. cholerae must express cholera enterotoxin (CT), the colonisation factor toxin-coregulated pilus (TCP) and the global regulatory element ToxR [6]. The major virulence factor produced by $V$. cholerae is CT, encoded by two contiguous genes that form the $\operatorname{ctx} A B$ operon [7]. Not

Received 20 Sept. 1996; revised version accepted 15 April 1997.

Corresponding author: Ms. Y-H. Shangkuan. all $V$. cholerae $\mathrm{O} 1$ strains are toxigenic and they may not be pathogenic. Strains of non-toxigenic 01 have been isolated from sewage, oysters and surface water [8].

Epidemiological studies of cholera have been hindered by the limited discrimination provided by phenotypic characteristics of $V$. cholerae 01 strains $[9,10]$. Molecular characterisation of $V$. cholerae $\mathrm{O} 1$ isolates have also proved difficult. Multilocus enzyme electrophoresis (MEE), which analyses stable 'housekeeping' enzymes, could not distinguish among widely distributed strains within the seventh pandemic [5, 11]. Ribotyping, which uses labelled Escherichia coli rRNA to probe the ubiquitous and polymorphic rDNA loci [12], is now widely accepted as a powerful epidemiological tool. Several studies [13-15] have been performed on the epidemiological application of ribotyping of $V$. cholerae isolates. Despite the broad applicability of this technique, its use in clinical microbiology laboratories has been limited because it is time-consuming and labour-intensive. Pulsed-field gel electrophoresis (PFGE) [16] is generally more discriminating than MEE and ribotyping. However, PFGE requires tedious cell preparation in agaroseembedded plugs, and lengthy electrophoretic separations. 
Detection of genomic polymorphism can also be achieved by a variety of polymerase chain reaction (PCR)-based methods [17-19]. Low stringency PCR with random oligonucleotide primers generates polymorphic DNA products from diverse species of eukaryotic and prokaryotic organisms $[18,19]$. Other primers designed to amplify DNA regions between moderately repetitive elements such as repetitive extragenic palindromes or enterobacterial repetitive intergenic consensus (ERIC) sequences are also capable of identifying interstrain genotypic diversity [20]. PCR genome fingerprinting has the advantages of simplicity and rapidity conferred by the PCR procedure. Thus, it might be an easier alternative to the other well established molecular typing procedures.

For PCR fingerprinting, selecting primers that produce reproducible and easily interpretable DNA fingerprints is essential. Short primers (10 bases) [21-23] or ERIC primers [24] have been used elsewhere in PCR fingerprinting analysis to study $V$. cholerae. Primers based on VCR (a repetitive sequence from $V$. cholerae) [25], ERIC sequence, and ERIC-related sequence in $V$. cholerae were used in a previous study to discriminate various $\mathrm{O} 1$ and non-O1 isolates [26]. The same primers were combined with each other in PCR to assay $V$. cholerae $\mathrm{Ol}$ isolates in this work. In addition, one random amplified polymorphic DNA (RAPD) primer was used. The combined PCR fingerprinting results of three different primer sets were compared with ribotyping, with 21 toxigenic 01 and 26 non-toxigenic $\mathrm{O} 1$ strains isolated in Taiwan and six toxigenic $\mathrm{Ol}$ strains obtained from abroad.

\section{Materials and methods}

\section{Bacterial isolates}

$V$. cholerae $\mathrm{O} 1$ isolates obtained in Taiwan were tested for toxigenicity both in the RPLA and the PCR [26, 27]. Six isolates were from cholera patients who had recently travelled to areas with endemic cholera (Indonesia and Thailand), one cholera case was of unknown origin. Eleven of the toxigenic isolates were isolated from seafood imported from different Asian countries. One of these toxigenic $O 1$ strains from Taiwan (NIPM N-002) was isolated in 1990, others were isolated during 1993-1995 (Table 1). Twenty-six 01 strains isolated from seafood and river water in Taiwan from 1992 to 1995 were found to be nontoxigenic (Table 2).

Three toxigenic 01 strains from a cholera epidemic in 1962 (NIPM T-165, T-166 and T-296) and a collection of six toxigenic $\mathrm{O} 1$ strains obtained from abroad (CCRC 12983; CDC E5906 and 2779-81; NCTC 10255,10256 and 10954) were also used in the study (Table 1). All $\mathrm{O} 1$ isolates listed above were of the El Tor biotype when tested in a multiplex PCR assay [26, 27].
All the isolates used in this study had been previously typed with repetitive element sequence-based PCR (rep-PCR) with three separate single primers [26].

\section{PCR primers}

The oligonucleotide primers were obtained from Genosys Biotechnologies Inc. (TX, USA). The following five primers were used: 5'-CCG CAG CCA A-3' (primer 1254); 5'-ATG TAA GCT CCT GGG GAT TCA C-3' (primer ERIC1R); 5'-AAC TGT GTG ATT AGG ATG AAC GAA-3' (primer VCl); 5'-CGC GTT GAC AGT CCC TCT TGA G-3' (primer VCR1); and 5'-TGG CGT TTC CAG TCC CAT TGA-3' (primer VCR2). Primer 1254 was a 10-mer arbitrary primer previously used in bacterial typing [28]; primer ERIC1R was designed by Versalovic et al. [20] from ERIC sequences; primer VCl was designed by us from ERIC-related sequences in $V$. cholerae [29, 30]; primers VCR1 and VCR2 were also designed by us from VCR, a repeated sequence associated with a locus encoding a haemagglutinin in $V$. cholerae $\mathrm{O} 1$ described by Barker et al. [25].

\section{DNA amplification}

Strains were streaked on Tryptic Soy Agar (Difco) and incubated at $37^{\circ} \mathrm{C}$ for $18 \mathrm{~h}$. A single colony was picked and cultured in $4 \mathrm{ml}$ of Luria-Bertani (LB) medium at $37^{\circ} \mathrm{C}$ for $4-6 \mathrm{~h}$ without shaking. Cultures were used at a McFarland turbidity of $2(6 \times$ $\left.10^{8} \mathrm{cells} / \mathrm{ml}\right)$. Two $\mu \mathrm{l}$ of whole-cell preparation were immediately used as the source of DNA template in PCR fingerprinting without centrifugation, washing or heating. The PCR reaction mixture $(50-\mu 1$ volume) contained 2.0 units of AmpliTaq DNA polymerase (Perkin Elmer), $10 \mathrm{mM}$ Tris- $\mathrm{HCl}$ (pH 8.5), $50 \mathrm{mM}$ $\mathrm{KCl}, 3.0 \mathrm{mM} \mathrm{MgCl}_{2}$, gelatin $0.01 \% \mathrm{w} / \mathrm{v}, 250 \mu \mathrm{M}$ (each) deoxynucleoside triphosphates and $0.5 \mu \mathrm{M}$ each of two opposing primers or $1.0 \mu \mathrm{M}$ for a single primer. Amplification was performed in a Thermal Cycler (MJ PTC-100-60) with temperature ramping as follows: (A) VCR1-ERC1R and VCR2-VC1 primers: $95^{\circ} \mathrm{C}$ for 5 min to denature template; four low-stringency cycles of $94^{\circ} \mathrm{C}$ for $5 \mathrm{~min}, 40^{\circ} \mathrm{C}$ for $5 \mathrm{~min}$ and $72^{\circ} \mathrm{C}$ for $5 \mathrm{~min}$; 30 high-stringency cycles of $94^{\circ} \mathrm{C}$ for $1 \mathrm{~min}, 55^{\circ} \mathrm{C}$ for $1 \mathrm{~min}$, and $72^{\circ} \mathrm{C}$ for $2 \mathrm{~min}$; and a final incubation at $72^{\circ} \mathrm{C}$ for $10 \mathrm{~min}$ [28]. (B) 1254 primer: $95^{\circ} \mathrm{C}$ for $5 \mathrm{~min}$ to denature template; four low-stringency cycles of $94^{\circ} \mathrm{C}$ for $1 \mathrm{~min}, 26^{\circ} \mathrm{C}$ for $1 \mathrm{~min}$, and $72^{\circ} \mathrm{C}$ for $2 \mathrm{~min} ; 40$ cycles of $94^{\circ} \mathrm{C}$ for $30 \mathrm{~s}, 40^{\circ} \mathrm{C}$ for $30 \mathrm{~s}$, and $72^{\circ} \mathrm{C}$ for $1 \mathrm{~min}$; and finally, $72^{\circ} \mathrm{C}$ for $10 \mathrm{~min}$ [31]. Amplification products $(20 \mu \mathrm{l})$ were separated by agarose gel electrophoresis in agarose 1.6 or $2.0 \%$ gels (Ultrapure DNA grade agarose, BioRad Labs, CA, USA) in $0.5 \times$ TBE $(0.045 \mathrm{M}$ Tris-borate, $0.001 \mathrm{M}$ EDTA) containing ethidium bromide $1.0 \mu \mathrm{g} / \mathrm{ml}$, at $150 \mathrm{~V}$ for $2-3 \mathrm{~h}$, and visualised by UV transillumination. Gels were photographed with a 60-s exposure to 
Polaroid type 667 instant film. The fingerprints obtained by PCR were compared visually.

\section{Ribotyping}

Chromosomal DNA was obtained and purified as described by Mekalanos et al. [32] and then digested with the restriction endonuclease BglI (New England Biolabs Inc., Beverly, MA, USA). The digested DNA was electrophoresed in agarose $0.8 \%$ gels and transferred to nylon membranes (Zeta-Probe, BioRad Laboratories) by Southern blotting [14].

The rRNA gene probe was a digoxigenin-dUTPlabelled stretch of c. $1500 \mathrm{bp}$ detecting 16S rRNA genes. They were synthesised by a one-step procedure based on the PCR method described by Liesack et al. [33]. The two primers were 5'-AGA GTT TGA TCC TGG CTC AG-3' (position 8-27 of $E$. coli $16 \mathrm{~S}$ rRNA) and 5'-GGT TAC CTT GTT ACG ACT T-3' (positions 1510-1492) [34], respectively, and were produced by Genosys Biotechnologies Inc. Briefly, PCR was performed in a $100-\mu 1$ reaction mixture with 2.0 units of AmpliTaq DNA polymerase (Perkin Elmer), $1 \mu \mathrm{M}$ of each primer, $200 \mu \mathrm{M}$ of each of the deoxynucleoside triphosphates dATP, dCTP, dGTP, $180 \mu \mathrm{M}$ of dTTP, $20 \mu \mathrm{M}$ of digoxigenin-dUTP (Boehringer Mannheim), and $2 \mu \mathrm{l}$ of whole-cell suspensions from toxigenic $V$. cholerae $\mathrm{O} 1$ clinical isolate $\mathrm{N}-\mathrm{Hw}$. Amplification was performed in a Thermal Cycler (MJ PTC-100-60) with temperature ramping as follows: $95^{\circ} \mathrm{C}$ for $5 \mathrm{~min}$ to denature template; 30 cycles of $94^{\circ} \mathrm{C}$ for $1 \mathrm{~min}, 50^{\circ} \mathrm{C}$ for $1 \mathrm{~min}$, and $72^{\circ} \mathrm{C}$ for $1.5 \mathrm{~min}$; and finally $72^{\circ} \mathrm{C}$ for $2 \mathrm{~min}$ [35].

Nylon membranes with immobilised DNA restriction fragments were hybridised, and fragments were detected colorimetrically as described by Popovic et al. [14]. A digoxigenin-labelled HindIII digest of bacteriophage lambda (BM) was included in each gel.
The restriction fragment patterns were compared visually.

\section{Results}

\section{Ribotyping}

A total of 13 rRNA restriction patterns was observed after BglI cleavage (Tables 1 and 2; Fig. 1). Five different rDNA restriction patterns were defined among the 27 toxigenic $\mathrm{O} 1$ isolates (Table 1 and Fig. 1). Three isolates from the 1962 cholera epidemic in Taiwan fell into the same ribotypes (ribotype II), which showed fragments of $2.3,4.0,4.1,4.6,5.6,5.9,6.2,6.6,6.8$ and $9.3 \mathrm{~kb}$. Four toxigenic $\mathrm{O} 1$ reference strains including two 1961 Hong Kong isolates (NCTC 10255, NCTC 10256) also belonged to ribotype II. The 5.6-kb fragment shown in ribotype II strains was absent in the ribotype III strain which comprised only one isolate (toxigenic $\mathrm{O} 1$ reference strain NCTC 10954). Seventeen toxigenic $O 1$ strains isolated in Taiwan during 1993-1995 exhibited an identical band pattern, ribotype V. Compared with the strains with the ribotype II patterns, strains belonging to ribotype $\mathrm{V}$ lacked 4.0-, 5.6- and 6.8-kb fragments but displayed an additional fragment of $10.3 \mathrm{~kb}$. A 1990 Taiwan isolate of ribotype IV when compared to the ribotype $\mathrm{V}$ strains lacked a 2.3-kb fragment but showed an additional 5.6kb fragment. The ribotype IV isolate and a ribotype I isolate (toxigenic O1 reference strain CCRC 12983) also had the same 10.3-kb fragment as the ribotype $\mathrm{V}$ strains. Ribotyping of 26 non-toxigenic isolates from Taiwan revealed eight patterns (VI-XIII) not seen among the toxigenic isolates (Table 2 and Fig. 1).

\section{PCR fingerprinting}

The reproducibility of the PCR fingerprinting method was examined in all isolates by three independent reactions. No change in the DNA fingerprints was

Table 1. Distribution of 21 toxigenic $V$. cholerae 01 strains from Taiwan and six toxigenic 01 reference strains obtained from abroad according to PCR fingerprinting and ribotype patterns

\begin{tabular}{|c|c|c|c|c|c|c|c|}
\hline \multirow[b]{2}{*}{ Group } & \multirow[b]{2}{*}{ Strains(s) } & \multirow[b]{2}{*}{ Serotype } & \multicolumn{3}{|c|}{ PCR fingerprinting type with primers } & \multirow{2}{*}{$\begin{array}{c}\text { Designated PCR } \\
\text { type }\end{array}$} & \multirow[b]{2}{*}{ Ribotype } \\
\hline & & & 1254 & VCR1 + ERIC1R & $\mathrm{VCR} 2+\mathrm{VCl}$ & & \\
\hline 1 & CCRC 12983* & Ogawa & $1 \mathrm{~A}$ & $2 A$ & $3 \mathbf{A}$ & 1 & I \\
\hline 2 & CDC E5906* & Inaba & $1 \mathrm{~B}$ & 2B & 3B & 2 & II \\
\hline 3 & NCTC $10954^{*}$ & Ogawa & $1 \mathrm{C}$ & 2B & 3B & 3 & III \\
\hline 4 & CDC $2779-81^{*}$ & Inaba & $1 \mathrm{C}$ & $2 \mathrm{C}$ & $3 \mathrm{C}$ & 4 & II \\
\hline 5 & $\begin{array}{l}\text { NCTC } 10255^{*}, 10256^{*}, \\
\text { NIPM T-165, T-166, T-296 }\end{array}$ & Ogawa & $1 \mathrm{~A}$ & $2 \mathrm{~B}$ & 3C & 5 & II \\
\hline 6 & NIPM N-002 & Ogawa & $1 \mathrm{C}$ & $2 \mathrm{C}$ & 3B & 6 & IV \\
\hline 7 & $\begin{array}{l}\text { NIPM N-Hw, N-Ch, N-Lin, } \\
\text { N-Kuo, N-Liu, MMH M-1, } \\
\text { NQS 28426, V8, 28353, } \\
\text { V66, V73, V77, V80, } \\
\text { 01939, V59, V74, V178 }\end{array}$ & Ogawa & $1 \mathrm{~B}$ & $2 \mathrm{D}$ & $3 B$ & 7 & V \\
\hline
\end{tabular}

CCRC, Culture Collection and Research Center, Hsinchu, Taiwan, ROC; CDC, Centers for Disease Control and Prevention, Atlanta, GA, USA; NCTC, National Collection of Type Cultures, Public Health Laboratory Service, London; NIPM, National Institute of Preventive Medicine, Taipei, Taiwan, ROC; MMH, Mackay Memorial Hospital, Taipei, Taiwan, ROC; NQS, National Quarantine Service, Taipei, Taiwan, ROC.

${ }^{*}$ Reference strains obtained from abroad. 
Table 2. Distribution of 26 non-toxigenic $V$. cholerae 01 strains from Taiwan according to PCR fingerprinting and ribotype patterns

\begin{tabular}{|c|c|c|c|c|c|c|c|}
\hline \multirow[b]{2}{*}{ Group } & \multirow[b]{2}{*}{ Strains(s) } & \multirow[b]{2}{*}{ Serotype } & \multicolumn{3}{|c|}{ PCR fingerprinting type with primers } & \multirow{2}{*}{$\begin{array}{c}\text { Designated PCR } \\
\text { type }\end{array}$} & \multirow[b]{2}{*}{ Ribotype } \\
\hline & & & 1254 & VCRI + ERICIR & $\mathrm{VCR} 2+\mathrm{VCl}$ & & \\
\hline 8 & $\begin{array}{l}\text { NQS, W19, V47, V90, } \\
\text { V183 }\end{array}$ & Inaba & $1 \mathrm{D}$ & $2 \mathrm{E}$ & $3 \mathrm{D}$ & 8 & VI \\
\hline 9 & NQS, V17, V49 & Inaba & $1 \mathrm{D}$ & $2 \mathrm{~F}$ & $3 E$ & 9 & VI \\
\hline 10 & NQS V99 & Inaba & 1D & $2 \mathrm{E}$ & $3 F$ & 10 & VII \\
\hline 11 & $\begin{array}{l}\text { NQS W12, W18, V38, } \\
\text { V43, V76, V81, V96 }\end{array}$ & Ogawa & $1 \mathrm{D}$ & $2 \mathrm{G}$ & $3 F$ & 11 & VII \\
\hline 12 & $\begin{array}{l}\text { NQS V56, W17, V63, } \\
\text { V101, V103, V16 }\end{array}$ & Inaba & $1 \mathrm{E}$ & $2 \mathrm{H}$ & $3 \mathrm{G}$ & 12 & VIII \\
\hline 13 & NQS V34 & Ogawa & $1 \mathrm{E}$ & $2 \mathrm{H}$ & $3 G$ & 12 & IX \\
\hline 14 & NQS V72 & Ogawa & $1 \mathrm{E}$ & $2 \mathrm{H}$ & $3 \mathrm{H}$ & 13 & VIII \\
\hline 15 & NQS V44 & Ogawa & $1 \mathrm{~F}$ & $2 \mathrm{I}$ & 31 & 14 & $\mathrm{X}$ \\
\hline 16 & NQS V176 & Inaba & $1 \mathrm{G}$ & $2 \mathrm{~J}$ & $3 \mathrm{~J}$ & 15 & XI \\
\hline 17 & NQS V186 & Ogawa & $1 \mathrm{H}$ & $2 \mathrm{~K}$ & $3 \mathrm{~K}$ & 16 & XII \\
\hline 18 & NQS V104 & Ogawa & $1 \mathrm{I}$ & $2 \mathrm{~L}$ & $3 \mathrm{~L}$ & 17 & XIII \\
\hline
\end{tabular}

*NQS, National Quarantine Service, Taipei, Taiwan, ROC.
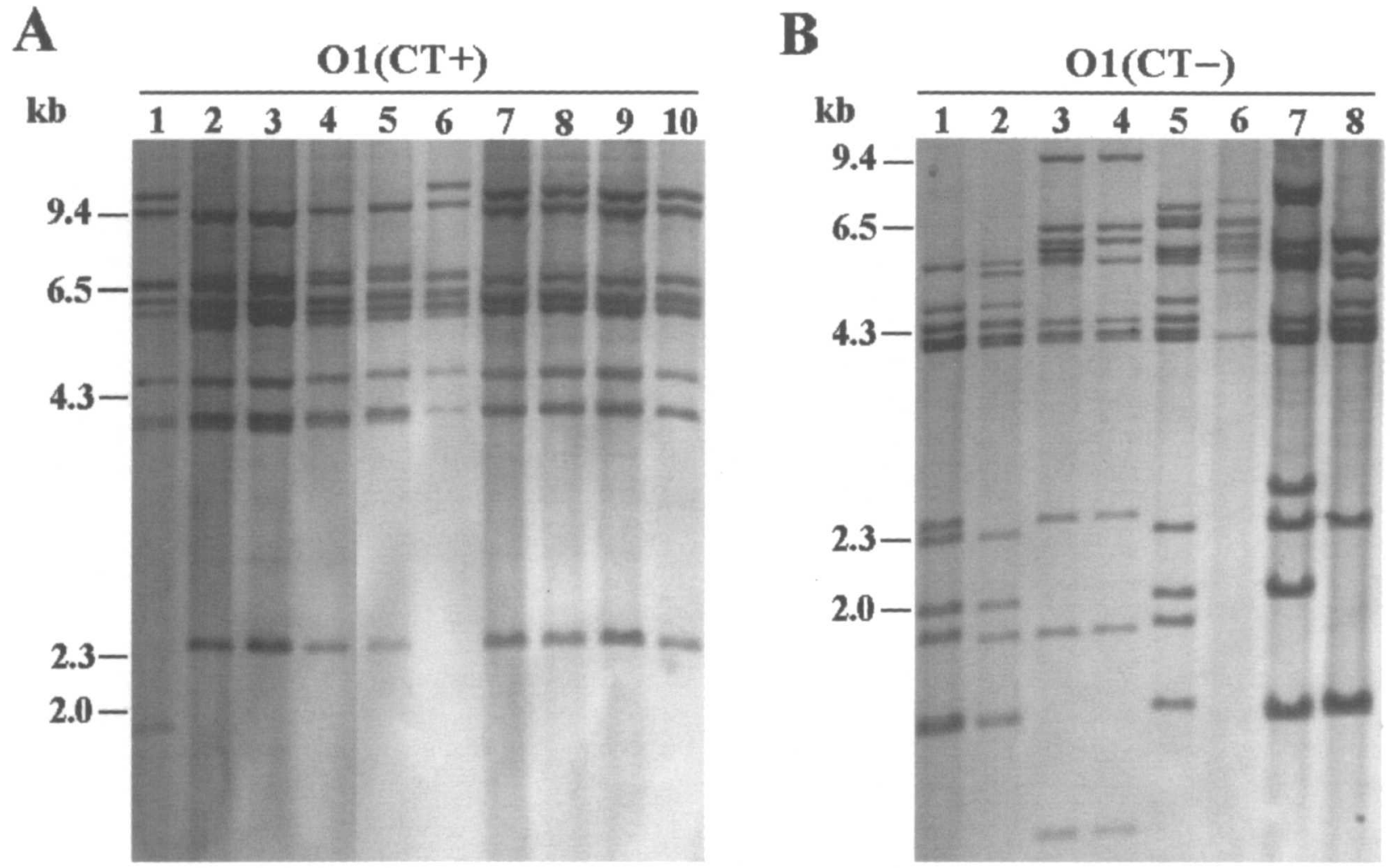

Fig. 1. Examples of BglI ribotyping of $V$. cholerae $O 1$ strains. (A) Toxigenic O1 strains; Lanes 1-4, reference strains CCRC 12983 (type I), CDC E5906 (type II), NCTC 10954 (type III) and CDC 2779-81 (type II), respectively; 5, isolate from 1962 cholera epidemic from Taiwan T-166 (type II); 6, isolate from imported case of cholera from Taiwan $\mathrm{N}-002$ (type IV); 7-9, isolates from imported cases of cholera from Taiwan N-Ch, N-Kuo and N-Lin, respectively (type V); 10, isolate from imported seafood 28353 (type V). (B) Non-toxigenic O1 strains: lane 1, W19 (type VI); 2, W12 (type VII); 3, V56 (type VIII); 4, V34 (type IX); 5, V44 (type X); 6, V176 (type XI); 7, V186 (type XII); 8, V104 (type XIII). Molecular sizes (kb) are indicated by numbers on the left.

observed in any of the three independent experiments (data not shown). In this study whole-cell suspensions were used as template DNA for amplification. The results were similar to those obtained with purified genomic DNA, but some differences were detected (data not shown).

PCR amplification of toxigenic and non-toxigenic $\mathrm{O} 1$ $V$. cholerae with the three primer sets listed in Tables
1 and 2 generated DNA products of $0.1-2.7 \mathrm{~kb}$. The number of distinct amplimer patterns observed among the $53 \mathrm{O} 1$ isolates depended on the primer set used: 1254 primers, nine patterns (1A-1I); VCR1 combined with ERIC1R primers, 12 patterns $(2 \mathrm{~A}-2 \mathrm{~L})$; and VCR2 combined with VCl primers, 12 patterns (3A3L) (Tables 1 and 2; Fig. 2).

When the combination of amplimer patterns generated 
A

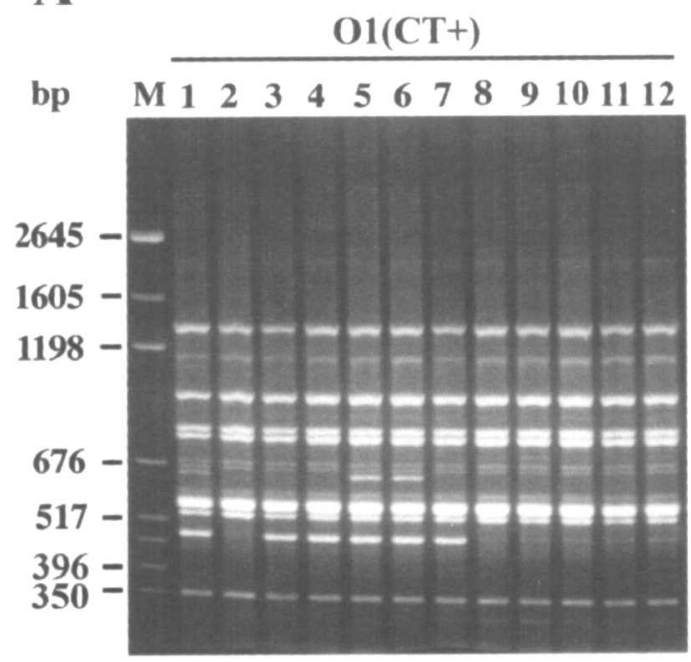

B

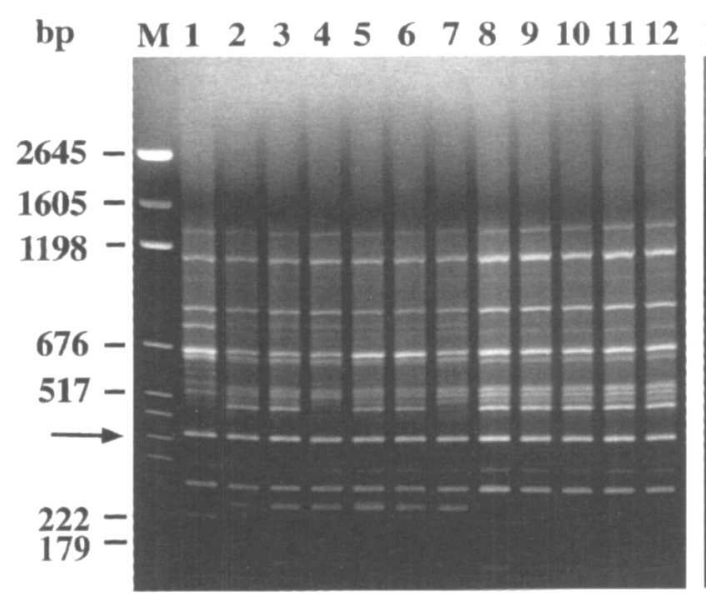

C

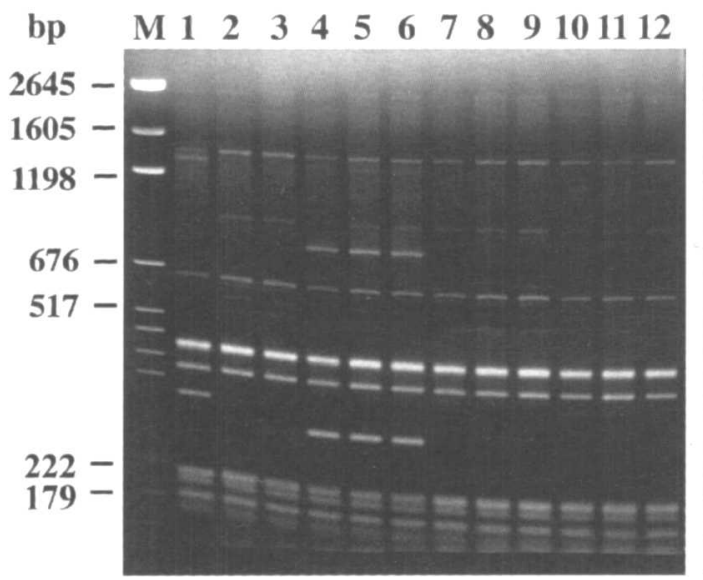

O1(CT-)

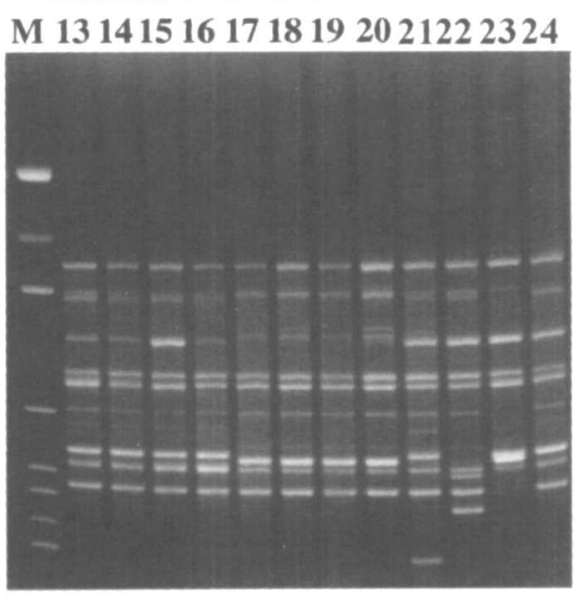

M 131415161718192021222324

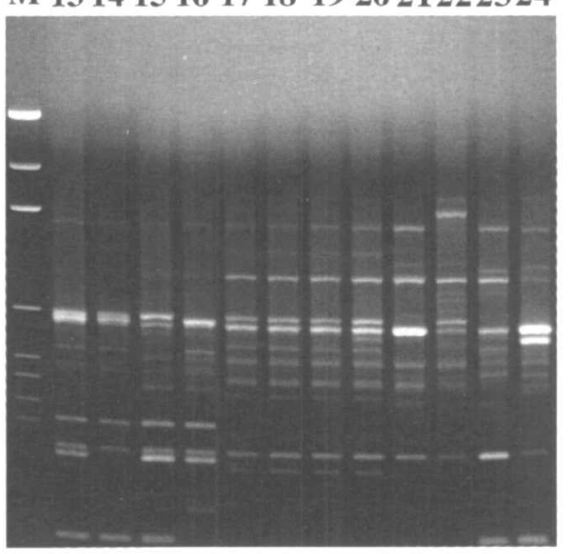

M131415161718192021222324

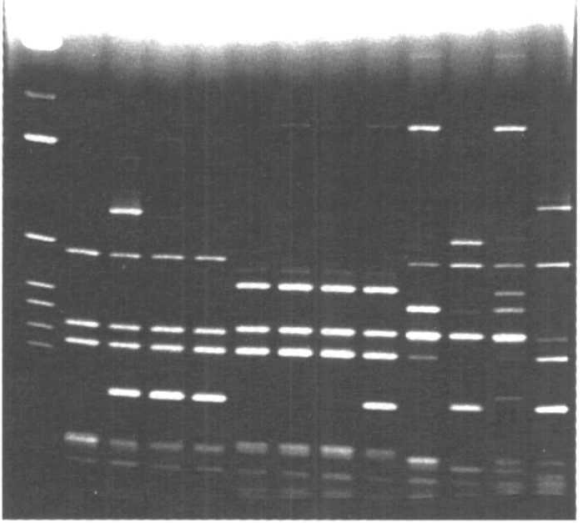

Fig. 2. Comparison of the PCR-fingerprinting patterns of representative toxigenic and non-toxigenic strains of $V$. cholerae O1. Three sets of primers, 1254 (A), VCR1-ERIC1R (B), and VCR2-VC1 (C) were used for PCR. Lane M, molecular size markers (pGEM; Promega); 1-5, toxigenic O1 reference strains CCRC 12983, CDC E5906, NCTC 10954, CDC 2779-81 and NCTC 10255, respectively; 6, toxigenic O1 isolate of 1962 cholera epidemic from Taiwan T$166 ; 7$, toxigenic 01 strain from imported case of cholera in $1990 \mathrm{~N}-002 ; 8-11$, toxigenic 01 strains from imported cases of cholera 1993-1995 N-Hw, N-Ch, N-Kuo and N-Lin, respectively; 12, toxigenic O1 isolate from imported seafood 01939; 13-24, non-toxigenic O1 isolates from seafood and river water in Taiwan W19, V17, V99, W12, V56, V16, V34, V72, V44, V176, V186 and V104, respectively. Note bands of c. 400-bp in all the toxigenic O1 strains with primer VCR1-ERIC1R. 
by all primer sets was used to define the PCRmediated DNA type, the 27 toxigenic 01 strains were subdivided into seven distinct types (labelled 1-7) (Table 1 and Fig. 2). Seventeen recent toxigenic strains isolated from imported food or imported cases of cholera had the type 7 pattern (Table 1). The type 6 pattern was represented by a single isolate from an imported cases of cholera in 1990. The type 1, 2, 3 and 4 patterns were each represented by single isolates which were reference strains obtained from abroad. Two reference strains and three isolates from the 1962 cholera epidemic in Taiwan generated indistinguishable fingerprints, represented by pattern 5 . All the toxigenic $\mathrm{Ol}$ strains showed a band of $c .400 \mathrm{bp}$ when primer pair VCR1-ERIC1R was used (Fig. 2B). This band was missing from all the non-toxigenic $\mathrm{O} 1$ strains.

Ten different PCR fingerprinting profiles were determined among the 26 non-toxigenic 01 strains isolated from Taiwan (Table 2 and Fig. 2). On the basis of their overall PCR fingerprinting patterns, patterns 10, $13,14,15,16$ and 17 were unique patterns exhibited by a single isolate each (Table 2 and Fig. 2). Two sets of seven isolates had the same fingerprints, which belonged to patterns 11 and 12 , respectively. Two and four isolates generated indistinguishable fingerprints represented by patterns 9 and 8, respectively. The PCR fingerprinting patterns of the 26 non-toxigenic $\mathrm{Ol}$ isolates were clearly different from those observed with the 27 toxigenic $\mathrm{O} 1$ isolates.

\section{Discussion}

Ribotyping, which uses labelled $E$. coli rRNA to probe the ubiquitous and polymorphic rDNA loci [12], is widely accepted as a powerful epidemiological tool. Popovic et al. [14] proposed a standardised scheme of 20 different $B g l \mathrm{I}$ ribotypes and subtypes based on the data from 198 human and environmental strains of $V$. cholerae $\mathrm{O} 1$ strains of the El Tor biotype. Their data showed that strains causing the current seventh cholera pandemic belong to several ribotypes (ribotypes 3-8). Ribotyping has the advantage of good reproducibility. The use of ribotyping as an epidemiological tool in assessing the relatedness of various strains of $V$. cholerae $\mathrm{O} 1$ has also been reported elsewhere [13, $15,36]$.

In this study, ribotyping produced five rRNA restriction patterns for the 27 toxigenic $\mathrm{O} 1$ strains. Seventeen recent toxigenic $\mathrm{Ol}$ isolates from imported seafood and imported cases of cholera belonged to ribotype V. Three isolates from the Taiwan 1962 cholera epidemic fell into ribotype II. Ribotype IV was represented by an isolate from an imported case of cholera in 1990 . When compared with the ribotype scheme of Popovic et al. [14], ribotypes II .. and III resembled ribotypes 3 and 5 , respectively. Strains showing ribotypes 3 and 5 have been isolated worldwide, with $\mathrm{O} 1$ strains from the Latin American epidemic displaying ribotype 5 and 01 strains from Indonesia in 1961 and from the Philippines in 1963 displaying ribotype 3 [14]. Ribotypes I, IV and V, which possessed a unique band of $10.3 \mathrm{~kb}$, resembled ribotype 6 of Popovic et al. [14]. Ribotype 6 is classified into three subtypes (subtypes $6 a-6 c$ ) and has exhibited diverse geographical origins; some of the strains originated in Asia and some in Mexico and Brazil [14]. Ribotype V resembled ribotype $6 a$. This ribotype contained a $2.3-\mathrm{kb}$ fragment which was absent from subtype $6 \mathrm{~b}$ and $6 \mathrm{c}$ isolates. In the same ribotype scheme of Popovic et al. [14], 19 nontoxigenic $\mathrm{O} 1$ isolates from nine countries are classified into nine ribotypes. In this study, the 26 non-toxigenic $\mathrm{O} 1$ isolates from Taiwan were separated into eight ribotypes which shows that the collection of nontoxigenic $\mathrm{Ol}$ strains in the present study were a more heterogeneous group than the toxigenic strains.

The well established PCR method can rapidly detect and identify organisms directly from clinical material and cultures. The PCR approach has also been used for intraspecies classification and typing of some clinically important bacteria. The PCR-mediated strain fingerprinting methods, such as RAPD and repetitive element sequence-based PCR (rep-PCR) have proved valuable for discriminating isolates of various eubacteria. Successful application of PCR fingerprinting depends heavily on the primer choice. In a previous study [26], various $V$. cholerae strains were examined in rep-PCR with different single primers, which included a VCR1 primer designed from the $V$. cholerae repetitive DNA sequence. The VCR1 primer could separate toxigenic El Tor strains into six groups [26]. The VCR1-ERIC1R primer combination used in this study separated the same kinds of strains into four groups. However, with the combination of results obtained with three different primer sets, these same strains could be separated into seven groups. Furthermore, a more conspicuous distinction among the toxigenic E1 Tor isolates was obtained with the combination of primers than with a single VCR1 primer. The VCR-ERIC1R primer combination showed a band of c. $400 \mathrm{bp}$ for all the toxigenic 01 strains. This band was missing from all of the non-toxigenic O1 strains. Compared to the previous study, the composite PCR types of non-toxigenic O1 strains from Taiwan also increased from eight to 10 [26]. The findings confirmed the importance of using a minimum of three different primers to generate a composite PCR fingerprinting profile, as also stated elsewhere [37].

Comparison of the results obtained with ribotyping and PCR fingerprinting showed that eight ribotypes had unique PCR patterns and PCR fingerprinting identified more than one pattern among isolates within each of the remaining ribotypes. However, ribotyping 
was able to differentiate between the same PCR types in one case. Overall, PCR fingerprinting divided 27 toxigenic $\mathrm{O} 1$ strains and 26 non-toxigenic $\mathrm{O} 1$ strains into seven and 10 PCR types, respectively, whilst ribotyping divided the same strains into five and eight types, respectively.

The RAPD technique carried out by other investigators does not allow a substantial distinction of strains within toxigenic El Tor isolates [22]. The ERIC-PCRgenerated fingerprints reported by Rivera et al. [24] could only differentiate $V$. cholerae $\mathrm{El}$ Tor isolates into toxigenic and non-toxigenic strains. In a previous study, a rep-PCR assay differentiated different toxigenic El Tor isolates into six groups [26]. In the present study, the same kinds of strains were separated into seven groups and a single ribotype and a single PCR fingerprinting pattern were found from both the imported seafood and the imported cases of cholera. Faruque et al. [36] reported that particular ribotyes were more frequently associated with epidemic cholera in Bangladesh. In view of the fact that cholera can be transmitted through food and water, monitoring the possible ribotype or PCR fingerprinting pattern responsible for epidemics in food and environmental water is of potential epidemiological importance.

In conclusion, the results of . PCR fingerprinting obtained with three different primer sets correlated well with those of ribotyping, but the method seems more discriminatory. Although more strains are needed to confirm the value of this technique, the PCR fingerprinting method could advantageously substitute the more cumbersome ribotyping techniques in determining relatedness or differences among $V$. cholerae $\mathrm{O} 1$ isolates. PFGE appears to be the most discriminating of several molecular subtyping methods in studies of $V$. cholerae $\mathrm{O} 1$ [16]. However, the PFGE method may take up to several days to complete. Furthermore, the PFGE patterns of $V$. cholerae $\mathrm{O} 1$ may be too numerous and analysis of these patterns may be too complex to be used in a general typing scheme [16]. PCR fingerprinting can be faster and easier to perform. Results can be obtained on the same day if whole-cell suspensions are used without treatment for template DNA in amplification reactions. The use of this rapid PCR procedure and subsequent PFGE analysis will be a highly effective combination of tools during epidemic episodes.

We thank Miss T. P. Liu and Mr H. S. Wu (National Quarantine Service), Dr T. M. Pan and Mr T. K. Wang (National Institute of Preventive Medicine) for providing $V$. cholerae strains used in this study.

\section{References}

1. Kamal AM. The seventh pandemic of cholera. In: Barua D, Burrows W (eds) Cholera. Philadelphia, Saunders. 1974; 1-14.

2. Wachsmuth K, Olsvik $\varnothing$, Evins GM, Popovic T. Molecular epidemiology of cholera. In: Wachsmuth IK, Blake PA, Olsvik $\emptyset$ (eds) Vibrio cholerae and cholera: molecular to global perspectives. Washington, DC, ASM Press. 1994: 357-370.

3. Benenson A. Cholera. In: Evans AS, Brachman PS (eds) Bacterial infections of humans. New York, Plenum Press. 1991: 207-225.

4. Finkelstein RA. Cholera, the cholera enterotoxins, and the cholera enterotoxin-related enterotoxin family. In: Owen $P$, Foster TJ (eds) Immunological and molecular genetic analysis of bacterial pathogens. Amsterdam, Elsevier/North Holland Science Publishing. 1988: 85-102.

5. Wachsmuth IK, Evins GM, Fields PI et al. The molecular epidemiology of cholera in Latin America. J Infect Dis 1993; 167: $621-626$.

6. Herrington DA, Hall RH, Losonsky G, Mekalanos JJ, Taylor RK, Levine MM. Toxin, toxin co-regulated pili, and the tox $R$ regulon are essential for Vibrio cholerae pathogenesis in humans. J Exp Med 1988; 168: 1487-1492.

7. Spangler BD. Structure and function of cholera toxin and related Escherichia coli heat-labile enterotoxin. Microbiol Rev 1992; 56: 622-647.

8. Almeida RJ, Hickman-Brenner FW, Sowers EG, Puhr ND, Farmer JJ, Wachsmuth IK. Comparison of a latex aggulutination assay and an enzyme-linked immunosorbent assay for detecting cholera toxin. J Clin Microbiol 1990; 28: 128-130.

9. Barrett TJ, Blake PA. Epidemiological usefulness of changes in hemolytic activity of Vibrio cholera biotype El Tor during the seventh pandemic. $J$ Clin Microbiol 1981; 13: 126-129.

10. Stroeher UH, Karageorgos LE, Morona R, Manning PA. Serotype convesion in Vibrio cholerae O1. Proc Natl Acad Sci USA 1992; 89: 2566-2570.

11. Chen F, Evins GM, Cook WL, Ameida R, Hargrett-Bean N, Wachsmuth $K$. Genetic diversity among toxigenic and nontoxigenic Vibrio cholerae $\mathrm{O} 1$ isolated from the Western Hemisphere. Epidemiol Infect 1991; 107: 225-233.

12. Stull TL, LiPuma JJ, Edlind TD. A broad-spectrum probe for molecular epidemiology of bacteria: ribosomal RNA. $J$ Infect Dis 1988; 157: 280-286.

13. Koblavi S, Grimont F, Grimont PAD. Clonal diversity of Vibrio cholerae $\mathrm{O} 1$ evidenced by rRNA gene restriction patterns. Res Microbiol 1990; 141: 645-657.

14. Popovic T, Bopp C, Olsvik Ø, Wachsmuth K. Epidemiologic application of a standardized ribotype scheme for Vibrio cholerae O1. J Clin Microbiol 1993; 31: 2474-2482.

15. Karaolis DKR, Lan R, Reeves PR. Molecular evolution of the seventh-pandemic clone of Vibrio cholerae and its relationship to other pandemic and epidemic $V$. cholerae isolates. $J$ Bacteriol 1994; 176: 6199-6206.

16. Cameron DN, Khambaty FM, Wachsmuth IK, Tauxe RV, Barrett TJ. Molecular characterization of Vibrio cholerae $\mathrm{O} 1$ strains by pulsed-field gel electrophoresis. J Clin Microbiol 1994; 32: 1685-1690.

17. Erlich HA, Gelfand D, Sninsky JJ. Recent advances in the polymerase chain reaction. Science 1991; 252: 1643-1651.

18. Welsh J, McClelland $M$. Fingerprinting genomes using PCR with arbitrary primers. Nucleic Acids Res 1990; 18: 7213-7218.

19. Williams JGK, Kubelik AR, Livak KJ, Rafalski JA, Tingey SV. DNA polymorphisms amplified by arbitrary primers are useful as genetic markers. Nucleic Acids Res 1990; 18: 6531-6535.

20. Versalovic J, Koeuth T, Lupski JR. Distribution of repetitive DNA sequences in eubacteria and application to fingerprinting of bacterial genomes. Nucleic Acids Res 1991; 19: 6823-6831.

21. Berche $\mathrm{P}$, Poyart $\mathrm{C}$, Abachin $\mathrm{E}$ et al. The novel epidemic strain $\mathrm{O} 139$ is closely related to the pandemic strain $\mathrm{O} 1$ of Vibrio cholerea. J Infect Dis 1994; 170: 701-704.

22. Coelho A, Vincente ACP, Baptista MAS, Momen H, Santos FARW, Salles CA. The distinction of pathogenic Vibrio cholerae groups using arbitrarily primed PCR fingerprints. Res Microbiol 1995; 146: 671-683.

23. Makino S-I, Kurazono T, Okuyama Y, Shimada T, Okada Y, Sasakawa C. Diversity of DNA sequences among Vibrio cholerae 0139 Bengal detected by PCR-based DNA fingerprinting. FEMS Microbiol Lett 1995; 126: 43-48.

24. Rivera IG, Chowdhury MAR, Huq A, Jacobs D, Martins MT, Colwell RR. Enterobacterial repetitive intergenic consensus sequences and the PCR to generate fingerprints of genomic DNAs from Vibrio cholerae $\mathrm{O} 1, \mathrm{O} 139$ and non-O1 strains. Appl Environ Microbiol 1995; 61: 2898-2904.

25. Barker A, Clark CA, Manning PA. Identification of VCR, a 
repeated sequence associated with a locus encoding a hemagglutinin in Vibro cholerae O1. J Bacteriol 1994; 176: 5450-5458.

26. Shangkuan YH, Lin HC, Wang TM. Diversity of DNA sequences among Vibrio cholerae $\mathrm{O} 1$ and non-O1 isolates detected by whole-cell repetitive element sequence-based polymerase chain reaction. J Appl Bacteriol 1997; 00: 000-000.

27. Shangkuan YH, Show YS, Wang TM. Multiplex polymerase chain reaction to detect toxigenic Vibrio cholerae and to biotype Vibrio cholerae O1. J Appl Bacteriol 1995; 79: 264-273.

28. Akopyanz N, Bukanov NO, Westblom TU, Kresovich S, Berg DE. DNA diversity among clinical isolates of Helicobacter pylori detected by PCR-based RAPD fingerprinting. Nucleic Acids Res 1992; 20: 5137-5142.

29. Sharples GJ, Lloyd RG. A novel repeated DNA sequence located in the intergenic regions of bacterial chromosomes. Nucleic Acids Res 1990; 18: 6503-6508.

30. Hulton CSJ, Higgins CF, Sharp PM. ERIC sequences: a novel family of repetitive elements in the genomes of Escherichia coli, Salmonella typhimurium and other enterobacteria. Mol Microbiol 1991; 5: 825-834.

31. Liu PY-F, Lau Y-J, Hu B-S et al. Analysis of clonal relationships among isolates of Shigella sonnei by different molecular typing methods. J Clin Microbiol 1995; 33: 17791783.

32. Mekalanos JJ. Duplication and amplification of toxin genes in Vibrio cholerae. Cell 1983; 35: 253-263.

33. Liesack W, Menke MAOH, Stackebrandt E. Rapid generation of vector-free digoxigenin-dUTP labeled probes for nonradioactive hybridization using the polymerase chain reaction (PCR) method. Sys Appl Microbiol 1990; 13: 255-256.

34. Weisburg WG, Barns SM, Pelletier DA, Lane DJ. 16S ,ribosomal DNA amplification for phylogenetic study. $J$ Bacteriol 1991; 173: 697-703.

35. Hiraishi A. Direct automated sequencing of 16S rDNA amplified by polymerase chain reaction from bacterial cultures without DNA purification. Lett Appl Microbiol 1992; 15: 210-213.

36. Faruque SM, Roy SK, Alim ARMA, Siddique AK, Albert MJ. Molecular epidemiology of toxigenic Vibrio cholerae in Bangladesh studied by numerical analysis of rRNA gene restriction patterns. $J$ Clin Microbiol 1995; 33: 2833-2838.

37. Farber JM, Addison CJ. RAPD typing for distinguishing species and strains in the genus Listeria. J Appl Bacteriol 1994; 77: 242-250. 